\section{Clinical and evolving features of women diagnosed with precancerous cervical lesions, screened and treated in the Amazon region of Brazil}

\author{
Características clínicas e evolutivas de mulheres \\ com diagnóstico de lesões precursoras de \\ câncer cervical, rastreadas e tratadas na \\ região amazônica brasileira
}

\section{Las características clínicas y los resultados \\ de mujeres con un diagnóstico de lesiones \\ precursoras de lesión cervical, seguimiento y tratamiento en la Amazonia brasileña}

\author{
1 Universidade Federal do \\ Acre, Rio Branco, Brasil. \\ 2 Escola Nacional de Saúde \\ Pública Sérgio Arouca, \\ Fundação Oswaldo Cruz, Rio \\ de Janeiro, Brasil. \\ 3 Instituto Nacional de Saúde \\ da Mulher, da Criança e \\ do Adolescente Fernandes \\ Figueira, Fundação Oswaldo \\ Cruz, Rio de Janeiro, Brasil. \\ Correspondence \\ P. R. Prado \\ Universidade Federal do Acre \\ BR 364, Km 4, Distrito \\ Industrial, C.P. 500 \\ Rio Branco, $A C$ \\ 69915-900, Brasil. \\ patyrezende@terra.com.br
}

\begin{abstract}
The objective of the study was to determine the dynamics of precancerous lesions in women of a cohort treated for cervical intraepithelial neoplasia (CIN) and followed up over the next two years. The conditional probability of failure was calculated using the Kaplan-Meier method, and the raw and adjusted hazard ratios (HR) were determined using Cox regression with a $p$-value entry of $<0.05$. Of the 237 women who were treated, $51.5 \%$ were accompanied over 24 months, and treatment failed for $21.9 \%$ of those accompanied. Women who had five or more pregnancies (adjusted HR $=3.10,95 \% C I$ : 1.28-7.51) or an initial histological diagnosis of CIN II/III demonstrated an independent risk of treatment failure (adjusted HR = 3.14, 95\%CI: 1.20-8.19). Being in a stable relationship was a protective factor against treatment failure (adjusted HR = 0.47, 95\%CI: 0.24-0.89). A history of more frequent pregnancies and a histological diagnosis of CIN II/III are directly correlated with risk of CIN treatment failure, whereas being in a stable relationship is inversely correlated with this risk.
\end{abstract}

Cervical Intraepithelial Neoplasia; Therapeutics; Cohort Studies
Patricia Rezende do Prado 1 Rosalina Jorge Koifman 2 Ilce Ferreira da Silva ${ }^{3}$

\section{Resumo}

O objetivo do estudo foi determinar a dinâmica da lesão intraepitelial cervical (NIC) em mulheres tratadas que foram acompanhadas em uma coorte durante dois anos. Foi calculada a probabilidade condicional de falha usando o método de Kaplan-Meier e foram calculadas as hazard ratios (HR) bruta e ajustada para o risco de falha usando a regressão de Cox com valor de $p$ de entrada $<0,05$. Das 237 mulheres que foram tratadas, 51,5\% foram acompanhadas por 24 me ses e 21,9\% delas tiveram falha no tratamento, apresentando recidiva da lesão cervical. Mulheres que tinham mais que cinco gestações (HR = 3,10; IC95\%: 1,28-7,51) ou histológico de NIC II/ III demonstraram risco independente para falha no tratamento $(H R=3,14$; IC95\%: $1,20-8,19) e$ estar em um relacionamento estável mostrou ser um fator de proteção para falha de tratamento (HR =0,47; IC95\%: 0,24-0,89). A história de maior número de gestações e histológico de NIC II/III estão diretamente correlacionados com o risco de falha no tratamento, enquanto que estar em um relacionamento estável é inversamente correlacionado ao risco.

Neoplasia Intraepitelial Cervical; Terapêutica; Estudos de Coortes 


\section{Introduction}

Cervical cancer is the second-most common neoplasia in women and is responsible for $15 \%$ of all cancers in women, representing approximately 500,000 new cases and 230,000 deaths per year worldwide 1,2 .

In Brazil, cervical cancer rates differ between regions, with estimated incidence rates in 2012 ranging from $15 / 100,000$ women in the Southeast Region to 24/100,000 in the North Region. This type of cancer has the highest incidence rate among women in the Amazon region ${ }^{3}$. The mortality rate associated with this neoplasia is also higher in the Amazon region, at 13.07/100,000 women and 16.95/100,000 women in the city of Rio Branco, Acre State, Brazil. In the Southeast and South regions, the estimated mortality rates are 10.32/100,000 and 5.82/100,000 women, respectively (DATASUS. Mortalidade Hospitalar por Residência: Taxa de Mortalidade por Câncer de Colo do Útero, 2011. http:// tabnet.datasus.gov. $\mathrm{br/cgi/deftohtm.exe?sih/cnv/nrac.def,} \mathrm{accessed}$ on 02/Mar/2012).

The human papilloma virus (HPV) infection is well known as a necessary, but not sufficient, risk factor for cervical cancer development 4,5. A set of co-factors is necessary in order for the cancer phenotype to arise, such as age, tobacco smoking, oral contraceptive use, immunosuppression, and host genetic susceptibility 5 . The normally slow development of cervical cancer allows for the identification of precancerous symptoms, classified as low grade (cervical intraepithelial neoplasia - CIN I and HPV during histological examination) or high grade (CIN II/ III during histological analysis) according to the probability of progression to cancer 6 . The main public health strategies to control cervical cancer development are screening through the Pap test and the excision of diagnosed lesions by LEEP (Loop Electrical Excision Procedure). However, the risk of treatment failure may vary from $5 \%$ $36 \%$ worldwide $7,8,9,10$.

Therefore, establishing an effective cytological screening program is an important method for cervical cancer control. However, implementing this program has been difficult in the Brazilian Amazon region, for a number of reasons including insufficient population coverage, poor quality of samples sent for examination, poor accuracy of the Pap smear test, lack of cervical intraepithelial lesion treatment, lack of follow-up, and treatment failure 11 .

Because Pap smear coverage rates are high in the target population (85.3\%) 12 of Rio Branco, a city in the Brazilian Amazon, this community is a good source of information for understanding and identifying factors that may correlate with the quality of cervical cancer screening in this region. Thus, this study sought to determine the epidemiological profile of women who were cytologically diagnosed with cervical intraepithelial lesions from 2007 to 2008 and subsequently treated in the public health system of Rio Branco. We also evaluated these patients for the two years following any treatment performed, taking into account behavior-outcome relationships and factors associated with the recurrence of cervical intraepithelial lesions.

\section{Methods}

This was a retrospective cohort study of women diagnosed with precancerous cervical lesions by Pap smear and reported to the Cervical Cancer Control Program (Programa de Controle de Câncer de Colo de Útero - PCCCU) in the city of Rio Branco. Data from the Cervical Cancer Information System (Sistema de Informação do Câncer de Colo do Útero - SISCOLO) in 2007 and 2008 were used as the source of this population study. In the state of Acre, all Pap test and histological slides are processed and analyzed in the same national public health Pathology laboratory (central pathology of Acre), which follows the Bethesda System to classify both cytological and histological exams as low grade (CIN I and compatible with HPV cytopathic effect during histological examination) or high grade (CIN II/III during histological analysis) 13 .

During 2007 and 2008, 48,729 women had a Pap smear test at public health centers in Rio Branco. Women who were screened for cervical cancer in Rio Branco were identified by SISCOLO. A total of 846 women had cytological alterations during those two years, 274 (32.4\%) of which had the lesion removed (by LEEP, biopsy, or cold-knife conization). Of these, 37 (4.4\%) of the women had cancer and were therefore excluded from this cohort; the remaining 237 women with precancerous lesions were treated and accompanied for 24 months in this study (Figure 1).

Following lesion removal, the medical records of those with cytopathological changes were obtained from the Acre Cancer Control Center (Centro de Controle Oncológico do Acre - Cecon) and the basic health units ("unidades básicas de saúde" - UBS). Medical records were identified by name, birth date, mother's name, and the identification number of the abnormal exam. Data were extracted using a standardized form that had been specifically designed for this purpose. 
Figure 1

Flowchart for selection of the study population. Rio Branco, Acre, Brasil, 2007-2008.

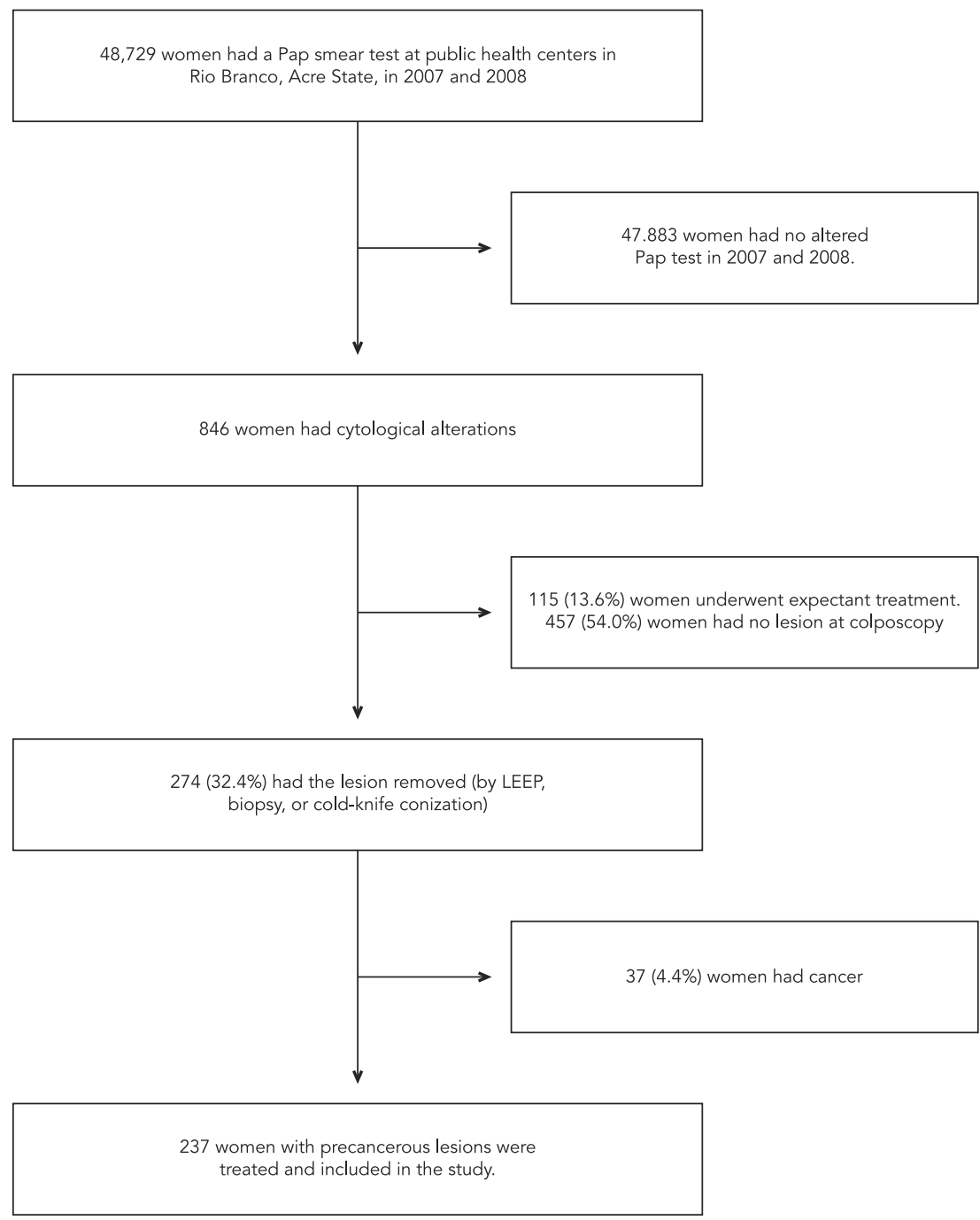

Variables for the following areas were collected: sociodemographic (age, marital status, and education level), epidemiological (smoking, age at first sexual intercourse, number of sexual partners, and oral contraception use), clinical (first histological exam, months of follow-up, cytology and treatment failure), and quality of screening and treatment (follow-up time in months and treatment performed).

Education level was classified as uneducated or number of years of school completed. Smoking was classified as never smoked, former smok- er, or current smoker. The cytopathological and histopathological results were classified using the Bethesda System, which was established in 2001 and classifies lesions as low grade (HPV and CIN I) or high grade (CIN II and CIN III) based on histology.

The criteria used in this study for evaluating the quality of cervical lesion screening and treatment were designated by the Ministry of Health, which recommends that low grade lesions should be reevaluated by cytology after six months. All repeat or high grade lesions should 
immediately be recommended for colposcopy at a middle complexity unit to verify the lesion. All patients with cervical cell changes who underwent lesion removal should be monitored for two years.

Time zero (T0) for this cohort was the date of removal of the precancerous lesion, and follow-up time $(\Delta \mathrm{T})$ was the time from $\mathrm{T} 0$ until the last cytological test identified in the 24 months of monitoring.

Any change in the CIN or identification of atypical squamous or glandular cells within the 24-month follow-up period was considered a failure. Women whose cytology remained clear up to the end of the study, who moved to another city, did not return to the unit for follow-up cytology, were censored on the date of the last visit. When this classification was due to loss of follow-up, the date of the last cytological exam was used.

To estimate the conditional probability of failure post-treatment after 6, 12, and 24 months of follow-up, we used Kaplan-Meier statistics. To evaluate differences in these conditional probability of failure curves, the $95 \%$ log-rank test was used.

To evaluate the risk factors associated with treatment failure, the Cox proportional hazards regression model was used to estimate the raw and adjusted hazard ratios with their respective 95\%CI (95\% confidence interval). The final model was constructed to evaluate prognostic factors of treatment failure. Independent variables that demonstrated statistical significance by univariate analysis were included in the Cox multivariate regression model, with $p$-value $<5 \%$ for entry and $\mathrm{p}$-value $>10 \%$ as the exclusion criteria for the model. Data were organized in Excel 2010 (Microsoft Corp, USA) and analyzed in SPSS 13.0 (SPSS Corp., Chicago, USA). This project was approved by the research ethics committee at the Federal University of Acre (Universidade Federal do Acre - UFAC).

\section{Results}

From 2007 to 2008, 237 women had precancerous lesions and underwent treatment, constituting the studied cohort. Women were monitored for an average of 18 months, while 122 women (51.5\%) were monitored for 24 months. Of the women followed, $52(21.9 \%)$ had a new lesion after treatment.

Other factors were as follows: $67.5 \%$ of the treated women were between 25 and 45 years old, $71 \%$ finished elementary school, $38 \%$ were smokers, and $90.9 \%$ used contraception. Approx- imately half of the women were classified as single $(54.5 \%), 31.3 \%$ became sexually active before 14 years of age, and $67.8 \%$ had had more than three pregnancies (Table 1). Histology revealed that $31.9 \%$ of lesions were HPV-positive, $22.4 \%$ were CIN I, and $45.7 \%$ were CIN II or CIN III.

The conditional probability of treatment failure at 24 months in women who were not in a stable relationship was $44.4 \%$ ( $\mathrm{L}-\mathrm{R} \mathrm{p}$-value $=0,025$ ), having more than five pregnancies also increased the risk of failure at 24 months $(52.9 \%$, L-R p-val$\mathrm{ue}=0,005)$. Also, women presenting histological diagnostic compatible with HPV cytopathic effect, CIN I, and CIN II/III presented a risk of treatment failure of $22.1 \%, 35.7 \%$, and $45.5 \%$, respectively $(\mathrm{L}-\mathrm{R}$ p-value $=0.030)$, (Table 1$)$.

Women who had had more than five pregnancies had a 3.10-fold risk of treatment failure compared to women who had had less than five pregnancies; this risk was independent of age, marital status, or histology upon entry. Similarly, women with an entering histological grade of CIN II/III also demonstrated an increased risk of treatment failure with an adjusted hazard ratio of 3.14 (95\%CI: 1.20-8.19). Conversely, being in a stable relationship was protective against treatment failure, with an HR of 0.47 (95\%CI: 0.24-0.89); this protection was independent of age, marital status, and number of pregnancies. Women who used oral contraception had increased risks for failure, although the estimates were not statistically significant (Table 2).

\section{Discussion}

In summary, the present study identified that $67.5 \%$ of women treated in the cohort were between 25 and 45 years old, $71 \%$ finished elementary school, $38 \%$ were smokers, and $90.9 \%$ used contraception. Approximately half of the women were classified as single (54.5\%), $31.3 \%$ became sexually active before 14 years of age, and $67.8 \%$ had had more than three pregnancies. Histology revealed that $31.9 \%$ of lesions were HPV-positive, $22.4 \%$ were CIN I, and $45.7 \%$ were CIN II or CIN III. These findings demonstrate the importance of providing adequate follow-up to women from Rio Branco, who have been diagnosed with precancerous cervical lesions.

Women who had had more than five pregnancies and those with entering histological grade of CIN II/III demonstrated an increased risk of treatment failure. Conversely, being in a stable relationship was protective against treatment failure; this protection was independent of age, marital status, and number of pregnancies. Women who used oral contraception had 
Epidemiological and clinical characteristics of women with cytological alterations and conditional probability of treatment failures. Rio Branco, Acre State, Brazil * $(N=237)$.

\begin{tabular}{|c|c|c|c|c|c|}
\hline \multirow[t]{2}{*}{ Variable } & \multirow[t]{2}{*}{$\mathrm{n}(\%) * \star$} & \multicolumn{4}{|c|}{$\%$ treatment failure (months) } \\
\hline & & 6 & 12 & 24 & $\begin{array}{c}\text { Log-rank } \\
(95 \% \mathrm{Cl})\end{array}$ \\
\hline \multicolumn{6}{|l|}{ Age (years) } \\
\hline$<25$ & $30(12.7)$ & 0.0 & 4.0 & 42.0 & \\
\hline $25-45$ & $160(67.5)$ & 0.7 & 1.5 & 31.0 & 0.149 \\
\hline$>45$ & $47(19.8)$ & 3.0 & 6.6 & 55.5 & \\
\hline \multicolumn{6}{|l|}{ Marital status } \\
\hline Stable union & $103(45.6)$ & 0.0 & 1.3 & 25.9 & 0.025 \\
\hline Not in a stable union & $123(54.4)$ & 1.0 & 2.0 & 44.4 & \\
\hline \multicolumn{6}{|l|}{ Education } \\
\hline Illiterate & $21(14.2)$ & 5.0 & 5.0 & 59.3 & \\
\hline Up to primary school & $84(56.8)$ & 1.4 & 4.7 & 35.4 & 0.348 \\
\hline > Primary school & $43(29.0)$ & 0.0 & 2.6 & 40.8 & \\
\hline \multicolumn{6}{|l|}{ Smoker } \\
\hline Yes & $57(38.0)$ & 2.1 & 4.2 & 28.8 & 0.285 \\
\hline No & $93(62.0)$ & 1.4 & 2.9 & 38.8 & \\
\hline \multicolumn{6}{|l|}{ First intercourse (years) } \\
\hline$<14$ & $66(31.3)$ & 1.8 & 3.7 & 43.5 & 0.085 \\
\hline$>14$ & $145(68.7)$ & 0.0 & 0.9 & 30.7 & \\
\hline \multicolumn{6}{|l|}{ Pregnancy } \\
\hline $1-2$ & $68(32.2)$ & 0.0 & 1.9 & 21.7 & \\
\hline $3-4$ & $73(34.6)$ & 0.0 & 1.9 & 35.1 & 0.005 \\
\hline$>5$ & $70(33.2)$ & 1.8 & 5.6 & 52.9 & \\
\hline \multicolumn{6}{|l|}{ Oral contraceptive } \\
\hline No & $6(9.1)$ & 0.0 & 0.0 & 0.0 & 0.248 \\
\hline Yes & $60(90.9)$ & 0.0 & 1.9 & 38.8 & \\
\hline \multicolumn{6}{|l|}{ Histology at entrance } \\
\hline HPV cytopatic effect & 74 (31.9) & 2.0 & 2.0 & 22.1 & \\
\hline $\mathrm{CIN} \mathrm{I}$ & $52(22.4)$ & 35.7 & 35.7 & 35.7 & 0.03 \\
\hline CIN II/III & $106(45.7)$ & 1.1 & 3.2 & 45.5 & \\
\hline \multicolumn{6}{|l|}{ Follow-up (months) } \\
\hline 6 & $38(16.0)$ & & & & \\
\hline 12 & $22(9.3)$ & & & & \\
\hline 12 to 24 & $177(74.7)$ & & & & \\
\hline 24 & $122(51.5)$ & & & & \\
\hline \multicolumn{6}{|l|}{ Histology of the failure } \\
\hline CINI & $18(34.6)$ & & & & \\
\hline $\mathrm{CIN} \|$ & $14(27.0)$ & & & & \\
\hline CIN III & $20(38.4)$ & & & & \\
\hline Total & 52 (21.9) & & & & \\
\hline
\end{tabular}

95\% Cl: 95\% confidence interval; CIN: cervical intraepithelial neoplasia; HPV: human papilloma virus.

* Kaplan Meier method;

** Total values may vary according to missing values.

increased risk of failure, although the estimates were not statistically significant.

The risk of treatment failure for precancerous lesions and the associated risk factors are criteria that must be analyzed when evaluating the efficacy of cervical cancer prevention and control programs. In this study, a $21.9 \%$ failure rate was observed. This finding is consistent with several 
Hazard ratio (HR) for crude and adjusted for relapse during treatment among women with CIN. Rio Branco, Acre State, Brazil.

\begin{tabular}{|c|c|c|}
\hline Variable & $\begin{array}{l}\text { Crude HR } \\
(95 \% \mathrm{Cl})\end{array}$ & $\begin{array}{l}\text { Adjusted HR } \\
(95 \% \mathrm{Cl}) \text { * }\end{array}$ \\
\hline \multicolumn{3}{|l|}{ Age (years) } \\
\hline 25 & 1.00 & 1.00 \\
\hline $25-45$ & $0.60(0.29-1.27)$ & $0.63(0.29-1.38)$ \\
\hline$>45$ & $1.14(0.49-2.67)$ & $1.12(0.46-2.73)$ \\
\hline \multicolumn{3}{|l|}{ Marital status } \\
\hline Not in a stable union & 1.00 & 1.00 \\
\hline Stable union & $0.55(0.30-1.00)$ & $0.47(0.24-0.89)$ \\
\hline \multicolumn{3}{|l|}{ Education } \\
\hline Illiterate & 1.00 & 1 \\
\hline Up to primary school & $0.61(0.27-1.34)$ & $0.49(0.19-1.26)$ \\
\hline$>$ Primary school & $0.69(0.28-1.67)$ & $0.50(0.17-1.48)$ \\
\hline \multicolumn{3}{|l|}{ Smoker } \\
\hline No & 1.00 & 1.00 \\
\hline Yes & $0.696(0.33-1.46)$ & $0.80(0.33-1.77)$ \\
\hline \multicolumn{3}{|c|}{ First occurance of intercourse (years) } \\
\hline$<14$ & 1.00 & 1.00 \\
\hline$>14$ & $1.67(0.92-3.04)$ & $1.56(0.82-2.96)$ \\
\hline \multicolumn{3}{|l|}{ Pregnancy } \\
\hline $1-2$ & 1.00 & 1.00 \\
\hline $3-4$ & $1.71(0.75-3.02)$ & $1.77(0.73-4.20)$ \\
\hline$>5$ & $2.85(1.35-6.03)$ & $3.10(1.28-7.51)$ \\
\hline \multicolumn{3}{|l|}{ Oral contraceptive } \\
\hline No & 1.00 & 1.00 \\
\hline Yes & $22.43(0.4-38.8)$ & $20.41(0.4-37.6)$ \\
\hline \multicolumn{3}{|l|}{ Histology at entrance } \\
\hline HPV cytopatic effect & 1.00 & 1.00 \\
\hline CIN I & $1.50(0.59-3.81)$ & $1.87(0.60-5.78)$ \\
\hline $\mathrm{CIN}\|\mathrm{e} C \mathrm{CIN}\| \mathrm{I}$ & $2.31(1.07-5.02)$ & $3.14(1.20-8.19)$ \\
\hline
\end{tabular}

95\% Cl: 95\% confidence interval; CIN: cervical intraepithelial neoplasia; HPV: human papilloma virus.

*Adjusted by marital status, first histology and age.

studies that observed recurrence rates of 5 to $35 \%$, although it is lower than that found in Rio de Janeiro, Brazil (31.7\%) 7,8,9,10.

The effect of exposures is additive over time; therefore, age is directly correlated with cervical cancer risk 1,3 . Several studies have shown that women who are older, have high-grade intraepithelial lesions, are black- or brown-skinned, have a history of multiple pregnancies, became sexually active at a young age, have had more sexual partners, or come from a low socioeconomic background are more likely to have cervical cancer and treatment failure 12,14,15,16,17.

Number of pregnancies was one of the factors associated with the highest probability of failure; by 24 months, the probability of failure was
$52.9 \%$ among women with a history of more than five pregnancies. The literature has shown that multiparity is associated with an increased frequency of cellular changes at the squamocolumnar junction. A higher number of pregnancies is likely correlated with low socioeconomic class, early initiation of sexual intercourse, and greater number of sexual partners 18. This risk factor is significant, but one that can be addressed by cervical cancer prevention and control programs.

Women who became sexually active early, i.e., before 14 years of age, demonstrated a higher probability of failure at 24 months $(43.5 \%)$ than women who became sexually active after this age. Our findings corroborate a study conducted in the United States, in which Hunter et al. 19 
reported that early initiation of sexual activity (before 16 years of age) was a risk factor for cervical cancer. The authors proposed that women who become sexually active at a young age are more likely to have multiple partners and, therefore, multiple HPV infections. The squamocolumnar junction may also be more vulnerable to HPV infection at a young age, when immunity is not completely developed 19 .

Women demonstrating histological changes consistent with CIN II and CIN III had a significantly higher probability of treatment failure at 24 months (45.5\%). Multivariate analysis also revealed a statistically significant risk of failure in women with CIN II/III (adjusted HR = 3.14; 95\%CI: $1.20-8.19$ ), independent of age, marital status, and number of pregnancies. This increased risk may reflect that more severe lesions have dysplastic cells in at least two-thirds of the epithelial thickness, making surgical excision less likely to succeed.

In a study of a hospital cohort in Rio de Janeiro, Silva et al. 14 also found that women with a histological diagnosis of CIN II or CIN III had a $28 \%$ chance of failure compared to women with CIN I/Metaplasia. The authors also identified a higher risk in women over the age of 50, women who had smoked for more than 10 years, and women who had more than four sexual partners in their lifetime.

Our study suggests that being in a stable relationship protects against treatment failure be- cause women who were not in a stable relationship had a $44.4 \%$ probability of failure at 24 months, while women in a stable relationship had a probability of only $25.9 \%$ during the same time period. The difference between curves was statistically significant. In addition, multivariate analysis resulted in a hazard ratio of 0.47 (95\%CI: 0.24-0.89) for women in a stable relationship compared to single women. This decreased risk may reflect the lower probability of having multiple partners among women in a stable relationship, thereby reducing opportunities for multiple HPV infections 18.

This study also benefited from its location in the Brazilian Amazon, which has the highest cervical cancer incidence and mortality rates in the country. To the best of our knowledge, this study is also the first conducted in the state of Acre, allowing us to assess the state's cervical cancer screening and prevention program.

\section{Conclusions}

These findings reinforce the need to implement socio-educational interventions that address cervical cancer risk factors in women from Rio Branco, including lectures and other educational activities that emphasize the influence of the number of pregnancies, age of first sexual intercourse, having a stable sexual partner, smoking, and preventive exams.

\section{Resumen}

El objetivo del estudio fue determinar la dinámica de las lesiones intraepiteliales de cuello uterino (NIC) en mujeres que fueron tratadas dentro de una cohorte, cuyo seguimiento se realizó durante dos años. Se calculó la probabilidad condicional de error, utilizando el método de Kaplan-Meier y se calcularon los cocientes de riesgo (HR) crudos y ajustados por el riesgo de fracaso mediante la regresión de Cox con el aporte valor $p<0,05$. De 237 mujeres que recibieron tratamiento, el 51,5\% fueron seguidas durante 24 meses y en el 21,9\% fracasó el tratamiento, mostrando la repetición del daño cervical. Las mujeres que tenían más de cinco embarazos (HR = 3,10; IC95\%: 1,28-7,51) o NIC histológico II/III mostraron un factor de riesgo independiente para el fracaso del tratamiento (HR =3,14; IC95\%: 1,20-8,19) y estar en una relación estable resultó ser un factor protector para el fracaso del tratamiento (HR: 0,47; IC95\%: 0,24-0,89). La historia de embarazos múltiples y con diagnóstico histológico NIC II/III se correlaciona directamente con el riesgo de fracaso del tratamiento, mientras que si está en una relación estable se correlaciona inversamente con la relación riesgo.

Neoplasia Intraepitelial del Cuello Uterino; Terapéutica; Estudios de Cohortes 


\section{Contributors}

P. R. Prado, R. J. Koifman and I. F. Silva designed, wrote, revised, and approved the study.

\section{Acknowledgments}

The authors thank Capes through the joint venture established between the Federal University of Acre (UFAC - Public Health Graduate Program) and the Graduate Program in Public Health and the Environment (ENSP/ Fiocruz), as well employees from Cecon/Acre for their assistance with this research.

\section{References}

1. Ferley J, Shin HR, Bray F, Forman D, Mathers C, Parkin DM. Estimates of wordwide burden of cancer in 2008: GLOBOCAN 2008. Int J Cancer 2010; 127:2893-917.

2. Jemal A, Bray F, Center MM, Ferley J, Ward E, Forman D. Global cancer statistics. CA Cancer J Clin 2011; 61:69-90.

3. Instituto Nacional de Câncer José Alencar Gomes da Silva. Estimativa 2012: incidência de câncer no Brasil. Rio de Janeiro: Instituto Nacional de Câncer José Alencar Gomes da Silva; 2011.

4. Ferenczy A, Franco EL, Ratnam, S. Human papillomavirus testing for primary screening of cervical cancer precursors. Cancer Epidemiol Biomarkers Prev 2000; 9:945-51.

5. Schlecht NF, Platt RW, Duarte-Franco E, Costa MC, Sobrinho JP, Prado JC, et al. Human papillomavirus infection and time to progression and regression of cervical intraepithelial neoplasia. J Natl Cancer Inst 2003; 95:1336-43.
6. Solomom D, Davey DD, Kurman RJ. The 2001 Bethesda System terminology for reporting results of cervical cytology. JAMA 2002; 287:2114-9.

7. Silva IFS, Koifman R, Mattos IE. Epidemiological characteristics related to treatment failure of preinvasive cervical intraepithelial neoplasia among Brazilian women. Int J Gynecol Cancer 2009; 19:1427-31.

8. Mitchell MF, Tortlero-Luna G, Cook E, Whittaker L, Rhodes-Morris H, Silva E. A randomized clinical trial of cryotherapy, laser vaporization, and loop electrosurgical excision for treatment of squamous intraepithelial lesions of the cervix. Obstet Gynecol 1998; 92:737-44.

9. Mohamed-Noor K, Quinn MA, Tan J. Outcomes after cervical cold knife conization with complete and incomplete excision of abnormal epithelium: a review of 699 cases. Gynecol Oncol 1997; 67:34-8. 
10. Paraskevaidis E, Lolis ED, Koliopoulos G, Alamanos X, Fotiou S, Kitchener HC. Cervical intraepithelial neoplasia outcomes after large loop excision with clear margins. Obstet Gynecol 2000; 95:828-31.

11. Zeferino LC. O desafio de reduzir a mortalidade por câncer do colo do útero. Rev Bras Ginecol Obstet 2008; 30:213-5.

12. Borges MFSO, Dotto LMG, Koifman RJ, Cunha MA, Muniz PT. Prevalência do exame preventivo de câncer do colo do útero em Rio Branco, Acre, Brasil, e fatores associados à não-realização do exame. Cad Saúde Pública 2012; 28:1156-66.

13. Instituto Nacional de Câncer. Nomenclatura brasileira para laudos citopatológicos cervicais. Rio de Janeiro: Instituto Nacional do Câncer; 2012.

14. Silva IFS, Koifman R, Mattos IE. Epidemiological characteristics related to treatment failure of preinvasive cervical intraepithelial neoplasia among Brazilian women. Int J Gynecol Cancer 2009; 19:1427-31.

15. Leal EAS, Leal Júnior OS, Guimarães MH, Vitoriano MN, Nascimento TL, Costa OLN. Lesões precursoras do câncer de colo em mulheres adolescentes e adultas jovens do município de Rio Branco - Acre. Rev Bras Ginecol Obstet 2003; 25:81-6.
16. Pioli ER, Oliveira NM, Rezende AG. Caracterização da demanda de pacientes com carcinoma de colo uterino no Hospital das Clínicas da Universidade Federal de Uberlândia, Minas Gerais, Brasil, 19841988. Cad Saúde Pública 1993; 9:421-7.

17. Guarisi R, Hardy E, Derchain SFM, Fonsechi-Carvasan GA, Borges JBR. Rastreamento, diagnóstico e tratamento das lesões precursoras e do câncer invasor de colo uterino no município de Franco da Rocha, SP. Rev Bras Cancerol 2004; 50:7-15.

18. Lima CA, Palmeira JAV, Cipolotti R. Fatores associados ao câncer do colo uterino em Propriá, Sergipe, Brasil. Cad Saúde Pública 2006; 22:2151-6.

19. Hunter RD. Carcinoma of the cervix. In: Peckham M, Pinedo HM, Veronesi U, editors. Oxford textbook of oncology. Oxford: Oxford University Press; 1995. p. 1324-48.

Submitted on $17 /$ Sep/2013

Final version resubmitted on 19/Feb/2014 Approved on 21/Feb/2014 